\title{
Dance movements of baksy as a paradigm of development of the Kazakh dance art
}

\author{
A. T. Moldakhmetova, G.T. Zhumaseitova, L.V. Kim, G.Y. Saitova, R. V. Kenzikeev \\ T. K. Zhurgenov Kazakh National Art Academy, the Republic of Kazakhstan. \\ Email:alimusha_88@mail.ru
}

Received May 15, 2018; Revised May 25, 2018: Accepted May 29, 2018; Published September 27, 2018.

\begin{abstract}
The interaction of traditional and innovative aspects in choreographic art leads to the emergence of a different palette of interpretations and stylizations of folk dance, and most frequently, in order to determine the most important aspects, there is a need to resort to its origins, management of the knowledge of traditional material, its early stages of formation. In this article, the authors investigated the origination of Kazakh dance from the shamanic dance. They revealed the influence of the dance element of shamanistic mysteries based on the comparison of examples of historical figurative artifacts and modernity. Using the method of paleochoreographic analysis of the images of shamanic dance, they revealed and presented the semantic load of the choreographic lexis of Kazakh dance, indicated the influence of religious viewpoint of Tengrism, and determined the types of imitative and ecstatic dance of the shaman. The article indicates the role of the knowledge of key bases of formation of national dance for future choreographers.
\end{abstract}

Keywords: Kazakh dance, baksy, specific position, visual artifacts, paleochoreography, tradition, innovation, shamanistic ritual.

\section{Introduction}

One of the leading choreographers of the XX century M. Bejart said: "Different nations' traditional dances are the bread and butter of choreographic searches" (Bejart 1989, p. 1). Admitting the words of the great maestro, at the present stage in the work of ballet masters, we observe very diverse forms of interaction between traditions and innovations in the direction of choreographic works. Because of this phenomenon, we have different palette of interpretations and stylizations of folk material.

This phenomenon has spread to Kazakh choreographic art, in particular, to the national Kazakh dance. Due to this, in ballet masters' performances we often observe dynamic transformation of choreographic lexis, mixed movements of male and female dance, and the combination of movements with heterogeneous semantic meanings sometimes creates a commonplace set of movements. Most often, when creating national ballet performances, ballet masters resort to another linguistic solution of traditional images - they use compositional forms, where the lexis of national dance is an integrated element, a subordinate unit in the hierarchy of plastic means of expression, rather than the basis of the artistic language.

However, any language is a cultural code that forms the philosophy of human life, his system of values, behavior, and a way of thinking. As early as in XVIII century German philosopher Gottfried Herder pointed out that, "Language is a necessary condition for the

(c) AesthetixMS 2018. This Open Access article is published under a Creative Commons Attribution Non-Commercial 4.0 International License (http://creativecommons.org/licenses/by-nc/4.o/), which permits non-commercial re-use, distribution, and reproduction in any medium, provided the original work is properly cited. For citation use the DOI. For commercial re-use, please contact editor@rupkatha.com. 
existence of a nation". For the existence of national dance, we should be concerned about maintaining its choreographic language (movements, eurythmics, manner and characteristics), that makes up its traditional image in the single context.

The masters of national choreographic art express the relevance of this issue in the sphere of national dance in the following manner: "Due to the influence of modern fashion, Kazakh dance, which is a unique manifestation of national culture, national consciousness, inexhaustible source for versatile researches, is currently undergoing certain evolution even in the most traditional forms. This shows the relevance of the issue of preservation of the dance, protecting it from pretentious pseudoscientific novelties, falseness. It complicates the task of recreating folk dance in its full splendor" (Izim and Kulbekova 2012; p. 19).

I.G. Esaulov once said: "The art of choreography is a science" (Esaulov 1995; p.78). Therefore, in order to solve the abovementioned problems, it is important to create conditions for preserving the foundation and platform connecting the horizons of the past, present and future of the Kazakh choreography. It is achievable through development and formation of the scientificresearch and scientific-methodical base of the national dance. Knowledge of the foundations of culture is a prerequisite for the competent creation of a certain laboratory of choreographic searches in the field of national dance.

Based on the presented actual problems, this article attempts to study the roots of the Kazakh dance in baksy dance art. This article also:

- considers the genesis of the movements of the Kazakh dance art, that is based on ritual and magic actions of shamans and baksy, testified by petroglyphs found on the territory of Kazakhstan.

- compares the images of ancient era and modernity.

- considers the role of Tengrian religious viewpoint in the origin of the movements of the Kazakh dance.

- attempts to decipher the semantic meaning of the movement 'ainalma', specific hand positions, poses.

- reveals the types and nature of shamanic dances.

- considers the role of the dancing movements of baksy as one of the manifestations of the phenomenon of 'baksylyk oner' (the art of baksy).

The object of study - Kazakh dance culture

The subject of study - dance movements of baksy in the monuments of material and spiritual culture of Kazakhstan.

\section{Methods of study:}

- comparative method;

- structural-semantic method;

- typological method;

- method of paleochoreographic analysis. 
When studying the development of Kazakh dance culture and the elements of archaic shamanic and baksy movements, the comparative method revealed the similarity of positions and poses of antiquity and modernity.

Structural-semantic method of analyzing the evidences of material and spiritual culture of Kazakhstan allowed revealing the semantic content of the dance lexis of the Kazakh dance.

Typological method of analysis led us to conclusion that the concept of "baksy" reveals the determining role of this word for the art and further development of national dance movements.

The method of paleochoreographic analysis let us determine the kinetics and statics of ecstatic and imitative dance, and let us reveal its semantics.

\section{Literature review}

In world science, there are a number of works devoted to the study of shamanism in various directions.

The works of foreign scientists like L.Y. Sternberg (1933), P.P. Shimkevich (1896), I.I. Georgi (1777) W.Knox (1877) present an interesting research of shamanic ritual, describing the use of identical attributes and ritual costumes.

Neil Price's work "Shamanism” (Price 2011) widely revealed the concept of shamanism.

Terje Oestigaard's work called "Cosmogony" (Oestigaard 2011) reviews cosmogonic worldview of the ancient inhabitants.

S.T. Makhlin's (2008) work, devoted to sacred religious representations of shamanism was of great interest in the field of semiotics.

The scientist M. Eliade's (2015) work presented a number of interesting facts about the features of the archaic technique of ecstasy in shamanistic rituals.

Totemic dances, that played an important role in the development of ethnic culture was discussed in the works of M.V. Amgalanov (2001) and O.B. Varlamov (1995).

Scientific researches of the candidate of historical sciences V.N. Basilov, developed in conjunction with his personal observations in the book "Chosen by the spirits" (Basilov 1984), reveal a critical analysis of shamanism as a peculiar and complex phenomenon in the history of religion.

In the history of the development of domestic science, many scientists took up the study of shamanism. We should highlight the works of following authors among them: $O$. Vsevolodskaya - Golushkevich (1996), A.B. Shankibaeva (Shankibaeva 2011).

The textbook "History of choreography of Kazakhstan" (Kishkashbaev, Shankibaeva, Mambetova, Jumaseitova and Musina 2005) is of particular interest. In this textbook Kazakh scientists revealed the specifics of the ritual practice of shamans, which is the basis for the emergence of early forms of dance art of the Kazakh people.

The area of presentation of the chronological phases and the influence of dance practice of shamans on the development of Kazakh dance was considered in the work "Theory and methodology of teaching the Kazakh dance" by A.K.Kulbekova and T.O. Izim (2012). 
While writing this article, it was interesting to address to the studies of the development of shamanistic ritual of the representatives of Turkic-speaking peoples.

Honoured Artist of Kazakhstan, Ph.D. in History of Arts, professor of the History of Arts G.Y.Saitova, in her monograph called "Uighur dance: Origins. Traditions. Stage impersonation" (Saitova 2011), searches for the origins of the Uighur dance. In this work, the author gives references to shamanic activity and considers healing rituals as a rudimentary form of theatrical performance.

The study of shamanistic rituals of Turkic-speaking peoples is considered in the works of A.M.Sagalaev, I.V.Oktyabrskaya (1990), dedicated to traditional world outlook of Turks in South Siberia.

Some information was drawn from the works of L.Avdeev, dedicated to the history of Uzbek national choreography. (Avdeeva 2000).

Genesis of shamanism among the Bashkirs and Karakalpaks is considered in the work of L.I.Nagaeva (1976).

Number of shamanistic rituals performed by the Sarts of East Turkestan was considered in the work of the Russian scientist S.E. Malov (1912).

The influence of shamanic art on the development of Korean dance was considered in the dissertation of the Doctor of Philosophy A.S.Tskhai (2016).

The shamanistic ritual represented a syncretic action that included singing, musical performance, dancing, acrobatics, therefore, to draw a parallel, the authors addressed to researches of scientists of traditional Kazakh musical and circus art.

PhD Dosbatyrov D.K. (2013) addressed to the art of shamans when studying the genesis of the circus art.

In addition, the research works required a comprehensive approach for the study and interpretation of rock paintings.

Among the foreign scientists who studied the petroglyphs of the gorges on the territory of Kazakhstan, we should point out the researches of Hoopwood C.E., Beardmore R. (2003), Hermann L.( Hermann 2011).

The scientist David S.Whitley (2011) performed the research of the images of shamans in rock paintings.

The leading Chinese scientist S. Gai $(1986,1993,1999)$, who studied petroglyphs, identified a number of shamanic images in rock paintings.

Studying the kinetics of anthropomorphic character in our work, we refer to the rock artifacts of antiquity with elements of dance movements, which testify to the fact that the tribes who lived in III-I millennia BC, had a syncretic dance art. It is described in the works of the following scientists: Margulan A.Kh. (2003), Okladnikov A.P. (1980), Bernstam A.N. (n. d.), Akishev K.A. (1978), Maksimova A.G. (1958).

The works of Medoev A. (1979), Samashev Z. (1998), Baipakov K.M. and Maryashev A.N (2004), Kadyrbaev M.K. and Maryashev A.N. (2007), Rogozhinsky A.E. (2011) let us consider the role of religious and philosophical traditions in the formation of national dance culture and investigation of its semantics. The scientist Z. Samashev disclosed interesting shamanic motifs in petroglyphs of East Kazakhstan in the following articles (Samashev 1993; Samashev 1998; 
Samashev 2002). The researches of the scientist Rozwadowski (2001a; 2001b) who studied the petroglyphs of Tamgaly in Kazakhstan, attracted our attention in terms of his analysis of a number of "shaman's" images.

The Russian scientist V. V. Romm (n. d.) studied the elements of dance movements in the monuments of rock art. The work of the scientist introduced us with the method of paleochoreographic analysis. This analysis made it possible to reveal the movements of Paleolithic dance movements.

The study of paleochoreography in the petroglyphs of Tuva was considered in the works of D.M.Sundui (2015).

The book by E. Koroleva "Early forms of dance" provided examples of interpretations of dance elements in ancient paintings (Koroleva 1977).

An interesting book by S. A. Tokarev "Religion in the history of the peoples of the world", where on the basis of reproductions of engravings on the walls of the Australian caves (Humbet, Northern Territory, Australia) (Tokarev 1965) the author assures about 14 dance plots performed by the shaman.

\section{The results of research}

The aim of this work is to reveal the influence of dance movements of baksy on the formation of the Kazakh dance.

- the nature of shamanic dance movements was revealed;

- baksy dance movements and choreographic lexis of Kazakh modern dance are compared and their similarities are identified;

- the semantics of baksy dance movements are revealed;

- the influence of Sun cult on the development of circular worldview, reflected in the circle dance, in the rotational movements of the hands called 'ainalma' is indicated; revealed;

- the influence of Tengrian religious belief on the emergence of baksy dance movements is

- the types of baksy dances are indicated;

- the influence of baksy dance movements on the formation of early folk Kazakh dance culture is specified.

- the description of the activities of baksy in the choreographic heritage of the Kazakh dance is presented.

There are various hypotheses about the origin of dance. According L.T. Dyakonova: "The origins of dance in the primeval era was both the dance spontaneously expressing the culmination of the emotional state of man in the movements, and the rites and ritual celebrations requiring certain regulation and semantics" (Dyakonova 2011). In the scientific literature, a significant part of the research explains the dancing activity of a primitive man as a consequence of religious ceremonies, magical mysteries that were mainly conducted by the shamans.

In the history of Kazakhstan science, the institute of shamanism is one of the main issues that the scientists address to study the origins of Kazakh dance. The scientists interpret the 
origins of shamanism as a consequence of various actions.

According to the scientist Neil Price: "The concept of shamanism progresses through three phases in its transition from the religion of indigenous peoples to its employment by academics, and this trajectory provides the key to its validity as a category of spiritual phenomena" (Price 2011, p. 987). The scientist Penglin Wang (2005) considers the emergence of shamanism from the perspective of anthropology and numerology.

The scientist I.N. Vinnikov explains the emergence of shamanism in the following way: "The improvement of the instruments of labor, the advent of new tools, new methods of work, new areas for the implementation of the tools expand the sphere of influence on nature. Various types of labor appear, the relationship between people in the production process becomes more complicated, and at the same time, people gain variety of positive knowledge, concepts and start to perform different magical acts. After all, the scope of these concepts and actions becomes so vast and diverse that every member of society is no longer able to master them. The representations about the spirit, its nature and properties become so complicated that communication with them requires certain persons with a special tendency and predisposition. Shaman - a person, who due to his inclinations, habitude, personal qualities, an ability to preserve, accumulate, multiply and develop the ideas, representations and traditions that have been developed by the society over centuries, who is able to successfully perform the spiritual functions of the society, to communicate with the supernatural world, the world of spirits with great success - appears during this period" (Vinnikov 1934, p. 140-141). The scientist O. Vsevolodskaya-Golushkevich expressed a similar idea in her book "Baksy oiyny”: “...there were first people who were specialized in the performance of magical and religious rituals and to some extent they became the creators of religious concepts and beliefs. Their emergence indicates the increasing social division of labor" (Vsevolodskaya-Golushkevich 1996, p. 27). The researcher of the activities of the representatives of Kazakh traditional culture E.Tursunov expresses his point of view: "The separation of shamans was the result of the social division of labor. People who were familiar with the rites were replaced by people specialized in this field" (Tursunov 1999, p. 97).

In the history of science, the term "shamanism" is interpreted differently. V. Dal dives the following interpretation: "Shaman is a wizard, magician of Siberian infidels" (Dal 1956, p.620). E. Zenovich believes that "shaman" (Evenki saman, sahan - excited, ecstatic man) is a sorcerer, healer of the Northern nationalities (Zenovich 2000, p. 709).

According to the definition of the scientist Ch.Ch.Walikhanov: "Shaman is a man gifted with magic and knowledge more than others. He is a poet, musician, visionary and a healer all in one. Kazakhs call them 'baksy', which in Mongolian means teacher. Uighurs call their educated people 'bakhsha' and Turkmen give this name to their singers" (Walikhanov 1985, p. 52).

Thus, the shamanism with ancient roots of origin represents "a multi-stage phenomenon typical of the eras of the communal-tribal system. It is an extensive system of animistic beliefs and cults of different peoples" (Moldakhmetova 2016, p.23). The shaman's activity is "a valuable historical source for the study of the theory of the origin of theatrical and dance art" (Tskhai 2016, p.44).

Therefore, providing in this article the examples of historical petroglyphic artifacts, testifying to the existence of shamanism in the territory of Kazakhstan in the early stages of development of humankind, we describe our attempts to disclose influence of shaman's ritual activity on formation of movements of the Kazakh dance. 
On the territory of modern Kazakhstan, "rock engravings as an artistic culture of ancient inhabitants, is presented in a wide scope" (Moldakhmetova 2016, p.14). They are found in such areas as: Terekty river valley, Khantau mountains, southwestern Lake Balkhash Region, Tushibek necropolis, South-Western slope of the Western Karatau ridge, Mangyshlak, Saimaly-Tash, Chulak mountains, the gorge of Tamgaly, Kulzhabasy. These archaeological complexes, previously studied by Western scientists, including Hoopwood C.E and Beardmore R, were recorded in the following way: "These areas in southern Kazakhstan contain thousands of petroglyphs dating from the Bronze Age through to the present day, creating a unique record of human activities" (Hoopwood and Beardmore 2003, p. 3). Numerous petroglyphs, as a chronicle of history, convey spontaneous dialectics of nomadic life, where "the recurrent motifs of this art are ritual dance scenes" (Moldakhmetova 2016, p. 14).

Tamgaly Gorge is known for its numerous historical images. Tamgaly is one of the brightest museums of rock paintings, ancient amphitheater, and a grand sanctuary. Petroglyphs within the Archaeological Landscape of Tamgaly was inscribed on UNESCO's World Heritage List by the World Heritage Committee which held its 28th session in China: "The dense and coherent group of petroglyphs, with sacred images, altars and cult areas, together with their associated settlements and burial sites (which) provide a substantial testimony to the lives and beliefs of pastoral peoples of the Central Asian steppes from the Bronze Age to the present day" (Moldakhmetova 2016).

One of the famous compositions of Tamgaly gorge with images of two "Sun-headed deities" aroused great interest among many foreign scientists. On this subject the archeologist Luc Hermann in his article "Rock Art of Tamgaly, Kazakhstan" states his idea on the sanctuary of visual artifacts in this way: "We can postulate that Tamgaly was a place of worship for the sun" (Hermann 2011, p. 26 - 40). The scientist Andrzej Rozwadowski, who studied the Tamgaly petroglyphs, analyzed many images of sun-headed deities, including the petroglyph "ritual dance" (Fig 1) during his expedition. According to this artifact, in an interview, the scientist claimed that the outlines of the heads of the two main characters give the idea of shamanic symbols, where "their heads that resemble the sun, look like the images of people in a state of trance (World Heritage List, n. d.]. Claiming that petroglyphs have shamanistic context, he put forward the concept of "graphic metaphors" and provided a new definition for those figures with heads resembling the sun, calling them "graphic metaphors of personal trance experiences" (Rozwadowski 2001a, p.16) or "graphic metaphors of shamanic rituals and the personal experiences of the shaman, performing certain rituals" (Rozwadowski 2001b, p.78).

This multi-figure composition with the image of people holding hands was the subject of a number of interpretations by many prominent Soviet and national archaeologists.

For example, the famous scientist P.I. Marikovsky wrote: "A group of people is dancing hand in hand. Another group of people opposite them is playing the instruments - bent sticks with tightened strings..." (Marikovsky 1950, p.78-79). A.N. Bernstam noted the explicit nature of the ritual scenes with the images of "ritual dance with the shaman, solar circles" (Bernshtam, $\mathrm{n}$. d., p.65).

Analyzing the scientists' interpretations of this artifact, Ph.D. in History of Arts, professor A.B.Shankibaeva in her book "Kazakh choreography: the development of forms and artistic means" gives her point of view in the following way: “...the image of sun-headed people and a walk around them was a representation of the sacred action. Hence, this kind of circle dance had a special meaning for the ancient people" (Shankibaeva 2011, p.18-19). Tangle of arms, similar position of the dancers' legs convey clockwise movement in circle, as if they are dancing a 
roundelay. According to the scientist E. Koroleva, different tangle of arms means the dancers' imitation of geometric forms of the celestial bodies, which then transformed into this kind of dance. These dances also express the symbol of sun and moon (Koroleva 1977, p.147).

The motif of a sun is a common phenomenon in petroglyphs of the world. The scientist V.M.Tikhonov associates the geometric motif of the circle in the petroglyphs of Korea with "the cult of Sun - the source of light and fertility" (Tihonov and Kan 2011, p. 59).

O. Vsevolodskaya - Golushkevich also writes about the solar symbol of the circle dance: "Light, sun, fire represented the power that creates life, - hence the veneration of this power, reflected in different epochs in the myths and different cults and hence the circularity of the ancient dances. Circle as a symbol of the sun, light and life reflects "virtuous", good principles of national, moral ideals of ancient times" (Vsevolodskaya-Golushkevich 1996, p. 23).

As in the interpretations of the scientists A. Rozwadowski, A.N. Bernstam, we clearly see the scene of a ritual on the images of petroglyphs. As the story goes, in ancient times, shaman was an important figure in the rituals. On the right corner of the image, we see interesting two characters. As if imitating the sun-headed deities, they are wearing the headdress with radially dispersing beams. In our opinion, it is the image of shamans performing a ritual of worshipping Sun God, and the group of people is performing the roundelay holding hands and moving their feet step by step. The composition of the image reflects the harmonious correlation of the main and secondary characters, where the main characters are two shamans, conveying the image of sun-headed deities, and the secondary characters are dancing characters performing the movements of the ritual - worshipping the Sun.

We see the dynamics of the development of the form of circle as a symbol of light and life in the healing circles and baksy's circles around a man.

In his researches, the scientist Ch.Ch. Walikhanov points out one peculiarity that takes place while performing the ritual: "their captivating power lies in these circular movements. Going around a man means taking upon all the spells that weigh upon him. Therefore, the word 'ainalaiyn' reflects the gentlest and the most truthful expression of love" (Walikhanov 1961, p. 483). The word 'ainalaiyn' literally means 'let me go around you'. In the choreographic lexis of Kazakh dance there is the basic hand movement and rotational movements called 'ainalma'. 'Ainalma' is a rotational movement of wrists figuratively drawing a circle.

In the structure of nomadic outlook, we can see the phenomenon of a circle in specific temporal aspect called twelve-year cycle of 'mushel', where "human life was believed to be a transition from one mushel to another, which implied the return to initial state, the end and the beginning of a new circle in living space at qualitatively different level. Figuratively speaking, the structure of unwinding spirals, was an important element of traditional thinking" (Zaurbekova and Dzhumanova 2000, p.57).

The movement of the hands 'ainalma' means the movement of a shaman around a man and it expresses an understanding that "Circularity, recurrence of different events, cycles of nature are interpreted as a continuous gradual ascent along the spiral, involving the augmentation of qualitatively new content" (Zaurbekova and Dzhumanova 2000, p. 55). 


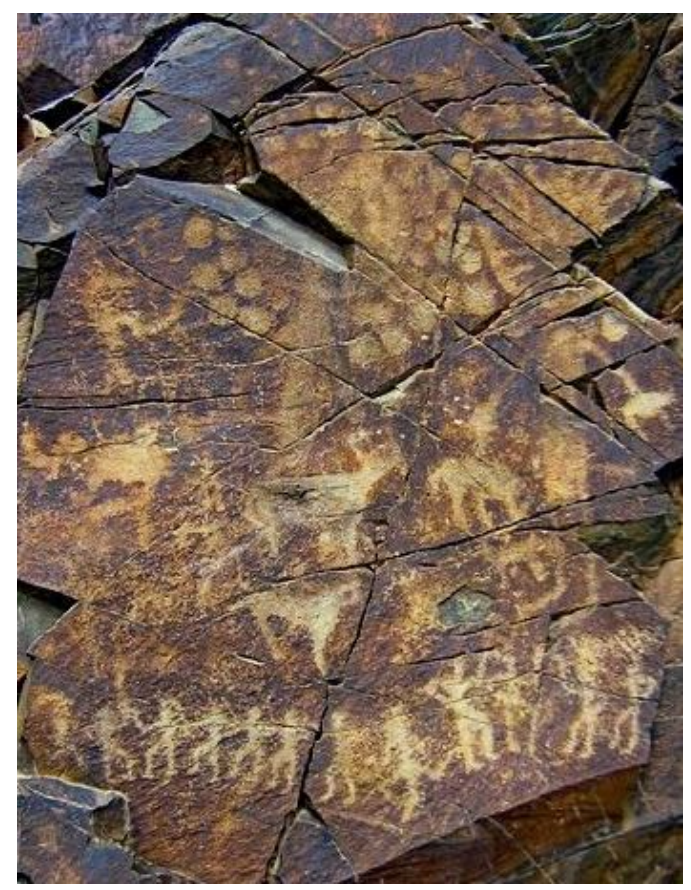

Figure 1 - Tamgaly. "Ritual dance” (Rogozhinsky 2011, p.232)

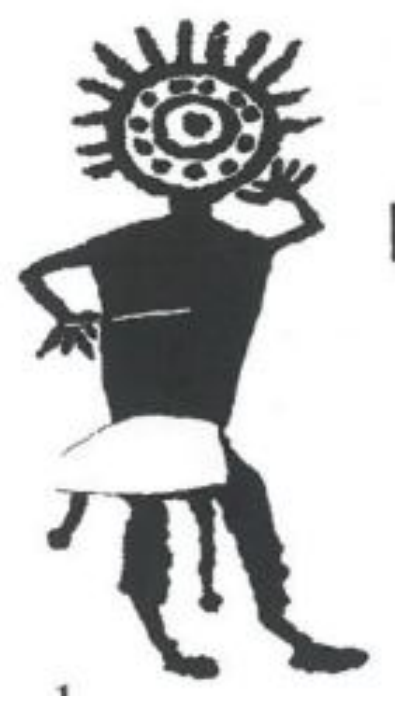

Figure 2 - Tamgaly.

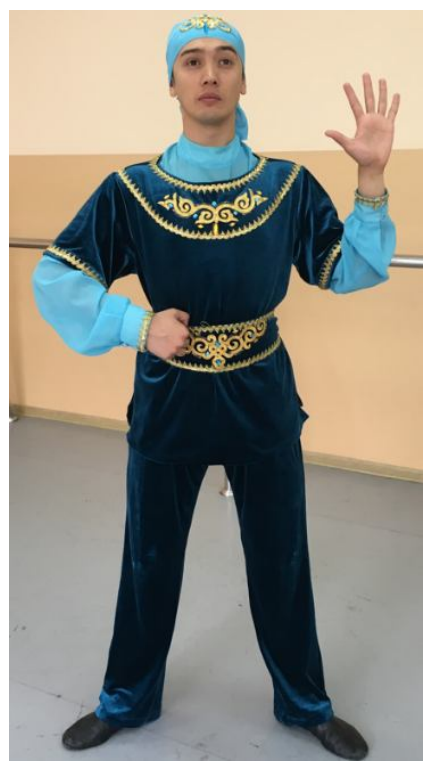

Figure 3 - 'Bes sausak' position

"Sun-headed deity"( Rogozhinsky 2011, p.188)

Another pictorial artifact called "Sun-headed deity" is also well known. We can see an open palm in this image. It is a shaman performing a ritual. In our opinion, his mask, as well as his right hand with extended fingers depict sunrays. Extended fingers of the left hand in our present day is known as the position of 'bes sausak' (five fingers). O. Vsevolodskaya-Golushkevich 
in her book " The school of Kazakh dance" explains the position of 'bes sausak' based on the ancient sign of creation. "It is an ancient position that emerged from the cult of sun. Extended fingers represent sunrays" (Vsevolodskaya-Golushkevich 1994, p.11). The scientist Z. Samashev in his book "Petroglyphs of Kazakhstan" interprets this position as "an anthropomorphic sign, dating back several thousand years, when the image of a wrist was a manifestation of partial magic and partially "replaced" a person" (Samashev 2006 , p.193).

Another composition is provided as an example from the book of A.Kh. Margulan. The scientist interprets this historical artifact in the following way: "One of the engravings called "shamans' ritual dance" is particularly admirable. It depicts a ceremonial scene: baksy, dancing ecstatically in front of sacrificial horses and figures of celestial gods and dancing people" (Margulan 2003, p. 16).

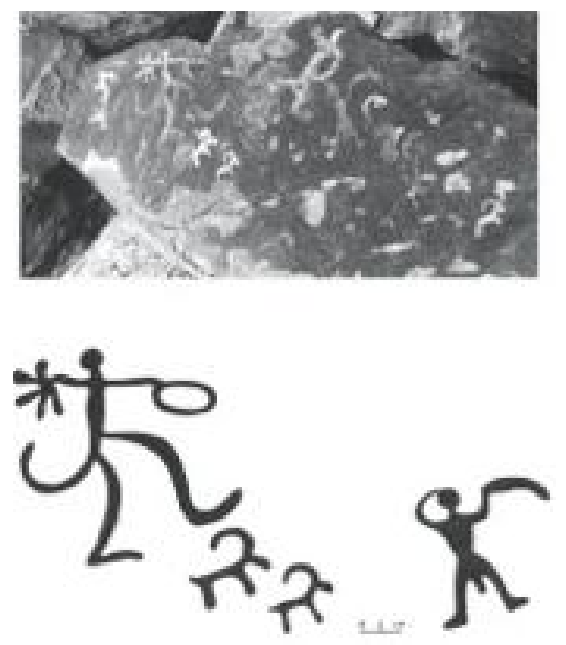

Figure 4- Sary-Arka "Ritual dance" (Margulan 2003, ph. 221)

Another interpretation of this sign is associated with fundamental ideological system of the great steppe - Tengriism. According to A.Y.Nikonov: "Tengriism as the worship of the deified sky, and the heavenly spirit, emerged in Paleolithic Age or even earlier... Tengriism is a worship of sky, which, being the most ancient cosmological and philosophical worldview, could not fail to have a marked influence on later religions (including world religions), as well as philosophy and literature" (Nikonov 2014, p.5). Cosmogony is a concept specific to ancient people and, "as a religious framework for understanding the world and the universe it necessitates specific types of interactions and rituals with divinities" (Oestigaard 2011, p.77). Therefore, it is likely that this attitude, as an expression of cosmological and philosophical worldview, is associated with Tengriism, which was the religious belief of ancient Turks, where the sky was believed to be a creator of all living beings. The Creator transmits his will through five main elements of nature: Sun, Earth, Water, Fire, Air. According to this version, the position of 'bes sausak' can be described as five categories, given by the Supreme God for the existence of mankind on Earth. Analysing the version of A.Margulan's interpretation about ritual character of the dance in SaryArka petroglyphs, we assume that the position of the fingers in the performance of baksy means five elements of nature, and the sacrificial horses depicted near mean the dedication as a tribute of praise. Thus, ritual dances of baksy performed in order to achieve a favorable attitude of nature, "were not the products of free artistic creativity, but the necessary element of a complex system of relationship with the world" (Dyakonova 2011, p.155). 


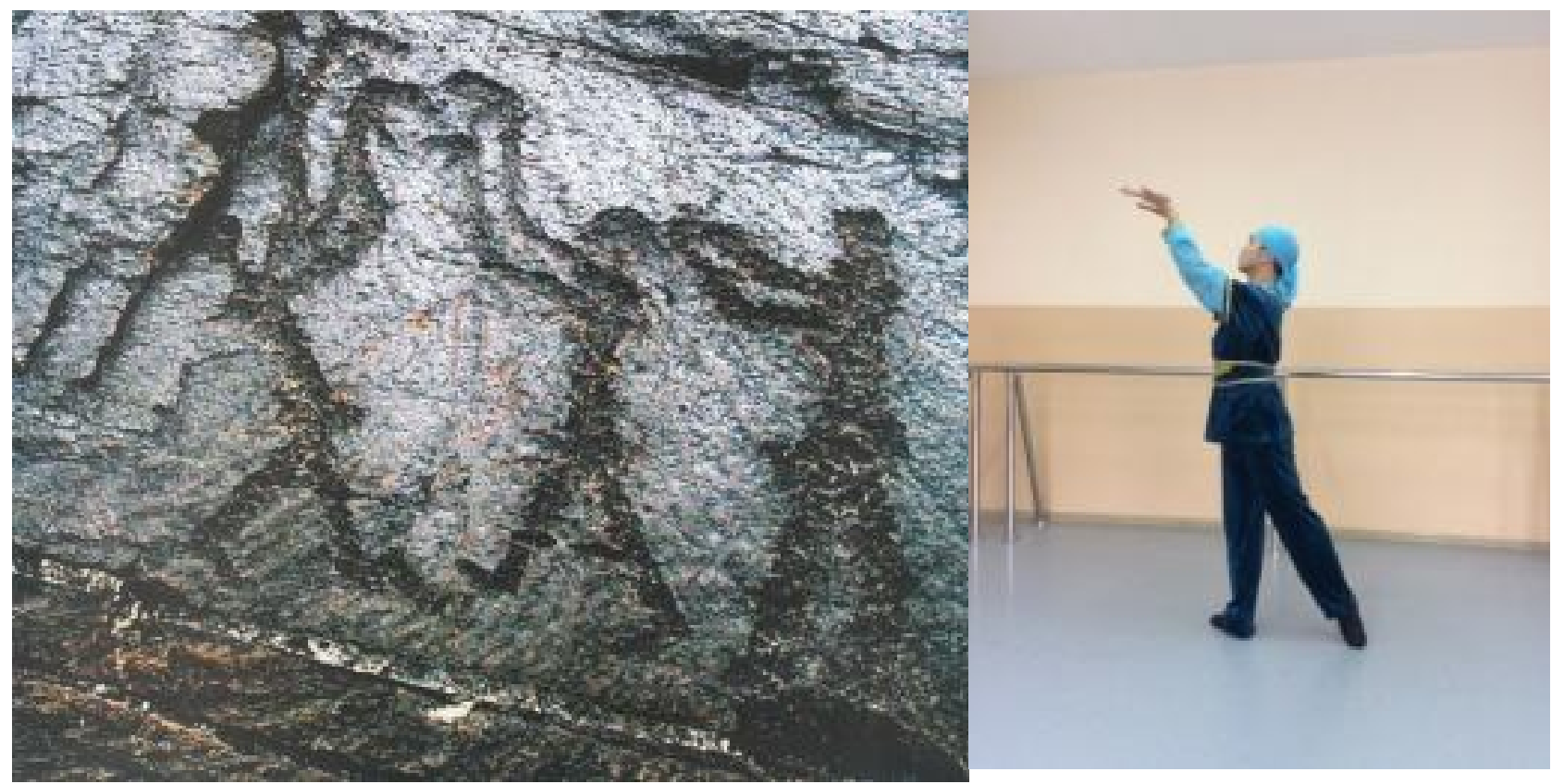

Figure 5 - Kuljabasy (Baipakov and Maryashev 20o4, ph.19)

Figure 6 - 'Ulken syilyk' position

In figure-5, baksy, holding arms upward with open palms, is worshipping the sky. According to such visual artifacts we can assume that in the mentality of ancient nomads, the spiritual fullness of the world where they lived, the feeling that the origins of everything are in heaven, was at the heart of their worldview. With a special intensity, the rock engravings convey the semantic unity of the real and fictional that is so peculiar to the worldview of the inhabitants of the Great Steppe. Figure-6 shows a similar situation, which exists in present days in the array of Kazakh dance movements called 'ulken syilyk' (big gift). According to the scientist Shankibaeva A.B: "Shamanic rituals involved the communication of baksy with spirits, therefore they started with the invocation of Tengri and spirits" (Shankibaeva 2011, p.27). Open palms depicted in the petroglyph are read as an appeal to the sky. We can find the statement similar to the one suggested by S. Gaius in the researches of another representatives of the ancient Turkic people, nomads of Northern Mongolia. The scientist interprets such images as shaman's images in the ritual of trance, worship of the sky, where the main purpose was the invocation of the gods, mediation between earth and heaven, between people and gods (Gai 1999, p. 157).

Shamanic practice assumed the ability to see the unmanifest part of the Universe. The ability to communicate with the spirits of ancestors characterizes his activity as a transport function. As a priest of Tengrian spiritual teaching, baksy honored the gods of the upper world, was able to defeat the evil and voluptuous spirits of the lower world, and in the middle world he could appease "the lords of the land". Thus, he performed the function of a mediator. We see the similar activities of baksy in the petroglyphs found in Bayan Zhurek mountains, 25 kilometers from the village Kapal in Almaty oblast. According to the scientist Z. Samashev, baksy is depicted at the time of the ritual act. The status of the shaman is described in the thesis of Dosbatyrov D.K.: "...from the ancient times the headdress has emphasized the status of the person, and it still retains its specificity in the crowns of the kings. ..., seven dispersing rays on shaman's head indicate his chosenness" (Dosbatyrov 2013, p.33). We interpret the arms stretched upwards, to the sky, as an appeal to the spirits, a crave for a strength, a prayer for a health. The hands that are put 
down are interpreted as a release from all bad things, and sending them to the underworld. We have mentioned above in the article that nomadic people called shaman 'baksy'. According to Kazakhstan scientists: "The word 'baksy' is derived from ancient Turkic word and is formed from the root 'bak-bag', which means 'to look out for' and reflects the basic essence of the shaman, consisting in looking out for stolen soul of the sick and knowledge of the future" (Kundakbaiuly, Ergalieva, Kuzembaeva, Zhumakova and Zhumaseitova, 2011, p. 214). The actions of the baksy, depicted in this composition tells us about the main purpose of baksy - healing an illness and communicating with the spirits of the upper and lower worlds acting as a mediator. In Kazakh dance, this position is called 'jogary-tomen', which means 'up and down'. Clear meaning of composition gives us the right to say that the activity of the baksy is permeated with dualistic classification that divides the world into binary oppositions (earth-sky, upper world-lower world (underworld), birth-death, evil-good).

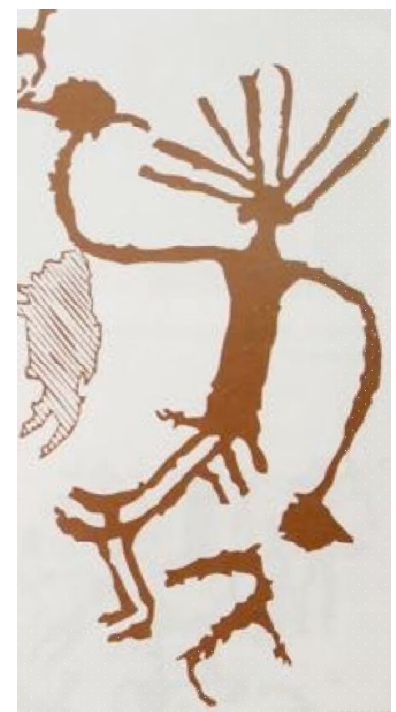

Figure 7-Bayanzhurek. Shaman.

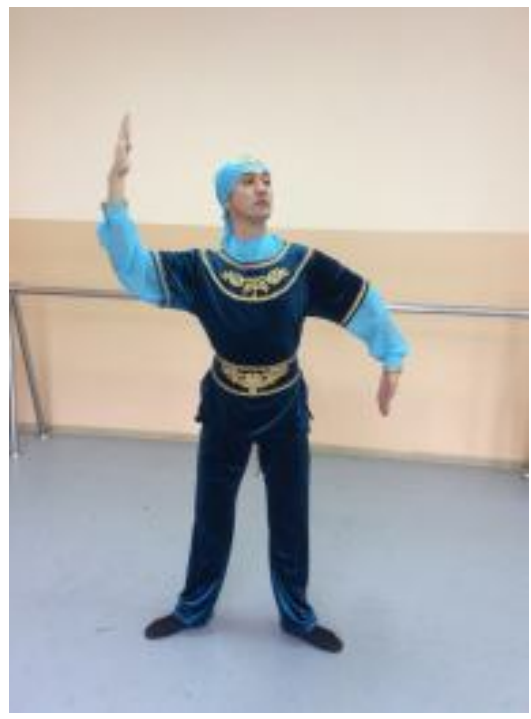

Figure 8 - 'Sharshy' position

(Samashev 2006, p.17o) 


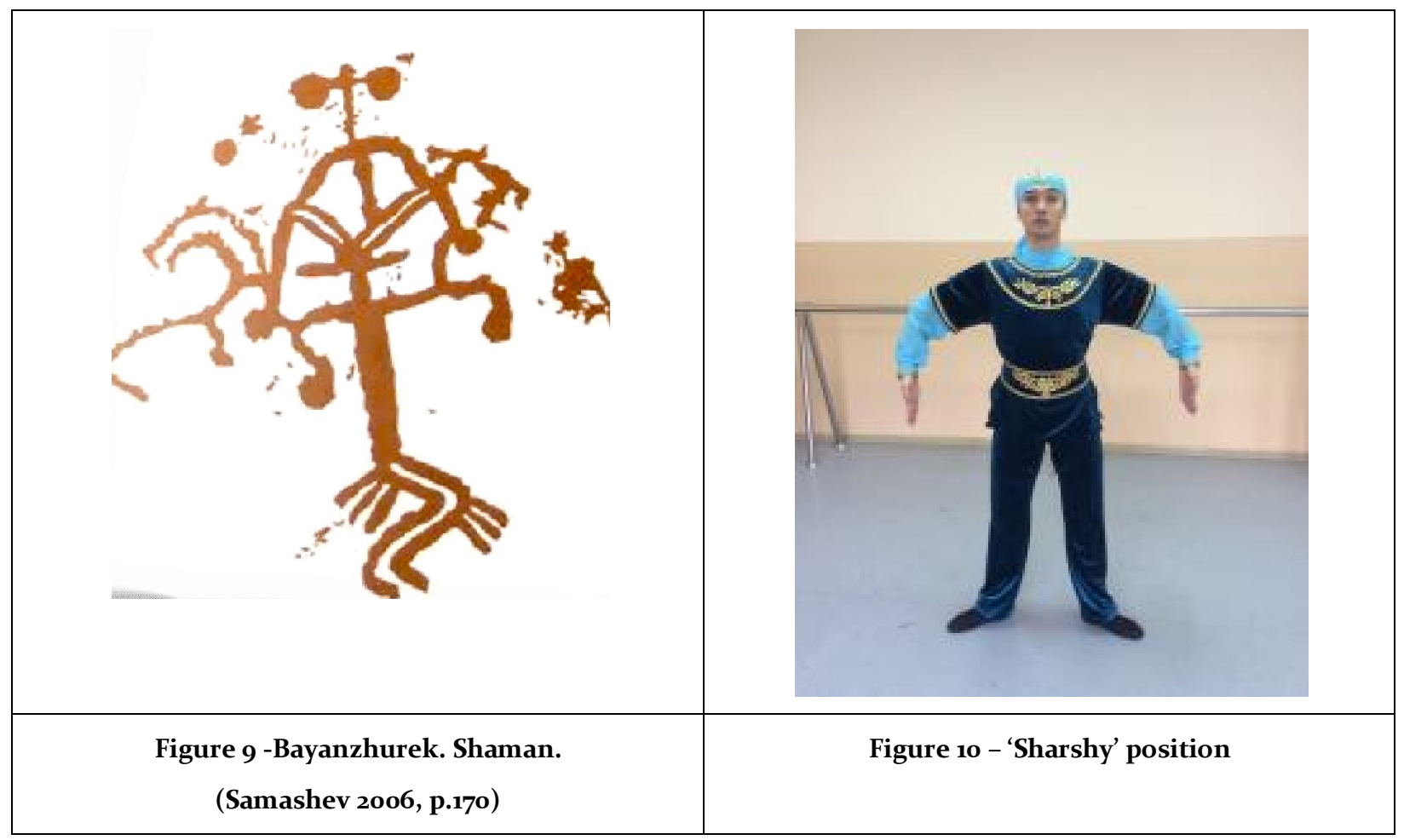

These images clearly reflect Tengrian picture of the world, which is described in OrkhonYenisey scripts (VII-VIII centuries), beginning with the lines: "In the beginning there was a blue sky above, and below a dark land...". Thus, the petroglyphs presented as an example (fig. 7-8) and the lines of ancient scripts express the value of basic concepts, equally important for a nomad in building the picture of the world.

Figure-9 shows the geometrical form that is called 'sharshy' (square) in Kazakh language. The square is associated with "reliability", "permanence" and "sedentism". Due to its "static" nature, it represents semantic opposition to such "dynamic" forms like circle, triangle and line. A square can correspond to four elements of universe (water, air, fire, earth), determine the cardinal points, and be associated with the life in this world. This geometric symbol with different forms and modifications is graphically and symbolically used in figurative and symbolic system of art of many countries and peoples. The Tengrians called this symbol 'tort kulak'. It symbolized four cardinal points and contained a wish of luck wherever a person was wending his way. Let us note that the word 'kulak' literally means an ear that, in our opinion, indicates a leading role of the organ of hearing and the necessity to strain ears to hear the cosmic order. Perhaps these movements were peculiar to the dance of baksy in the epoch of Huns, as "the Huns had these geometric motifs from simple to complex configurations - squares, rectangles, polygons, rhombus, star-shaped figures, crosses with complicated shape" (Ibragimova 2004, p. 209).

According to Dosbatyrov D.K., two discs in the image of Bayanzhurek shaman, meaning "two magic mirrors, pointing to the possibility of manipulating them in illusionary trick", indicate the shaman's mastership in circus skills (Dosbatyrov 2013, p.33). The scientist Tihonov associates the presence of mirrors in rock paintings with a cult of Sun. He wrote that mirrors had "special, ritual and magical sense. It was considered an important accessory of a priest or shaman, with the help of which the ministers of religion could "accumulate" a light (the basic component of the sacred space) in their hands and "control it" (Tihonov and Kan 2011, p. 51). Agreeing with the scientists, we also suggest our opinion that the mirror in shaman's hands at the top and bottom of 
the image in fig.7, as well shaman's headdress adorned with a vertical rod with discs in fig. 9 mean the symbol of the sun and the moon, and "a mythological space with a path of divine mediators in-between" (Samashev 2006, p.174).

In the robes of Bayanzhurek shamans, six fringes hanging down in threes from the knee and hip joint attract the attention. On this subject, Dosbatyrov D.K. says: "...they were attached to different areas of the shaman's ritual vestments and had highly significative function" (Dosbatyrov 2013 p. 34). Based on this, we can assume that the baksy took the preparation to the ritual very seriously, and each element was very important as for a theatrical act. They were carried out "in strict accordance with the laws of the theatrical genre: it implied the presence of a costume, decoration, outstanding performing skills, a combination of canon and improvisation, etc." (Sagalaev and Oktyabrskaya 1990, p.134). The use of identical attributes, the presence of a ritual costume have been emphasized many times by many scientists, among which there are the works of Sternberg L.J. (1933), Shimkevich P.P. (1896), Georgi I.I. (1777), Knox W. (1877).

Thus, having analyzed the figure-1,2,4,5,7,9, we believe that baksy communicated with the spirits through special raiment, the use of the attributes and movements of cosmogonic nature. Being between the worlds presupposes an ecstatic state of a baksy, which, according to David S. Whitley "is important in many religions, but it is a central component of shamanism, which maintains that an individual may have direct interaction with the supernatural world" (Whitley 2011, p.308).

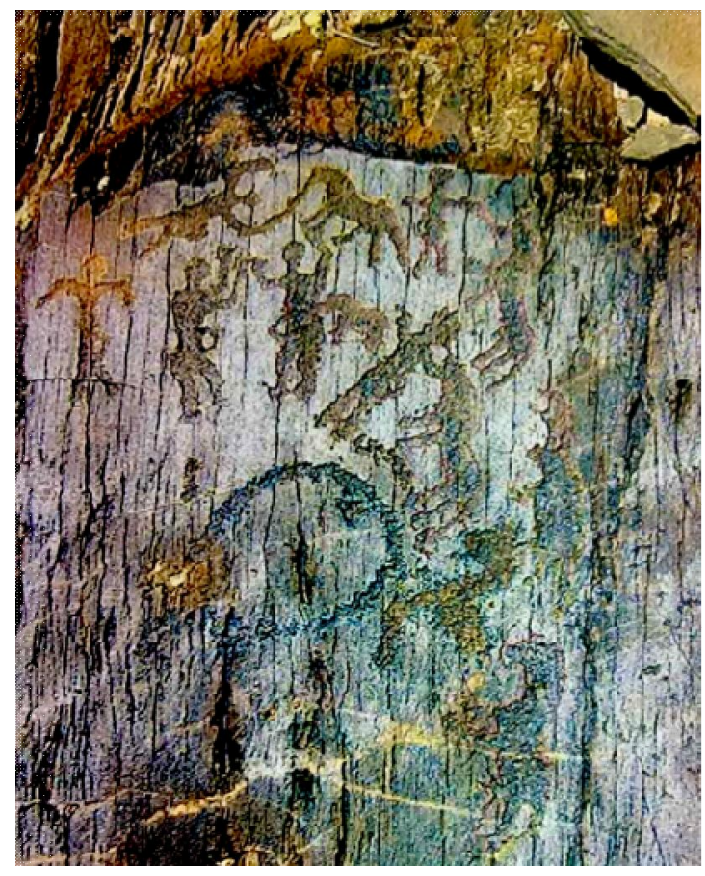

Figure 11- Kuljabasy (Baipakov and Maryashev 2004, ph. 7)

Baksy, drawing a certain image through a language of associative, figurative movements, could portray different images. We see such movements in visual artifacts of Kuljabasy mountains (fig. 11). This image depicts ritual ceremonies and sacrifices "around a sacred object with the participation of a large number of people" (Samashev 2006, p. 171). In our opinion, the petroglyph presented in the article does not exclude the possibility of the emergence of shamanism among Kazakhs, as well as among the representatives of Turkic peoples, like Bashkirs and Karakalpaks 
(Nagaeva 1976, p. 67-72).

The composition of Kuljabasy petroglyph depicts rite performed by shamans with participation of people and animals, which can be interpreted as a ritual of "shifting the illness" from person to objects, birds and animals. This action was spread among Turkic-speaking peoples. Russian scientist S.E. Malov describes the rite: “...a shaman transmits the disease into pigeon, chicken, goat” (Malov 1912, p.1-16). Bashkir scientist L.I.Nagaeva (1976) also noted that the Bashkir and Karakypchaks' rite of healing implied a sacrifice and transfer of the disease from a person to a rooster or goose.

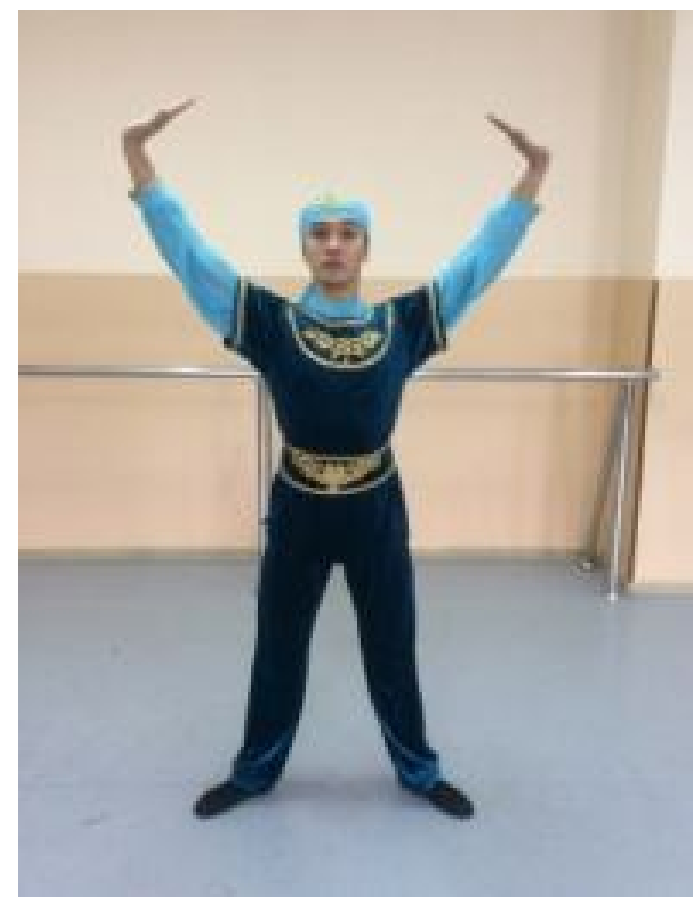

Figure 12 -'Burkit kanat' position

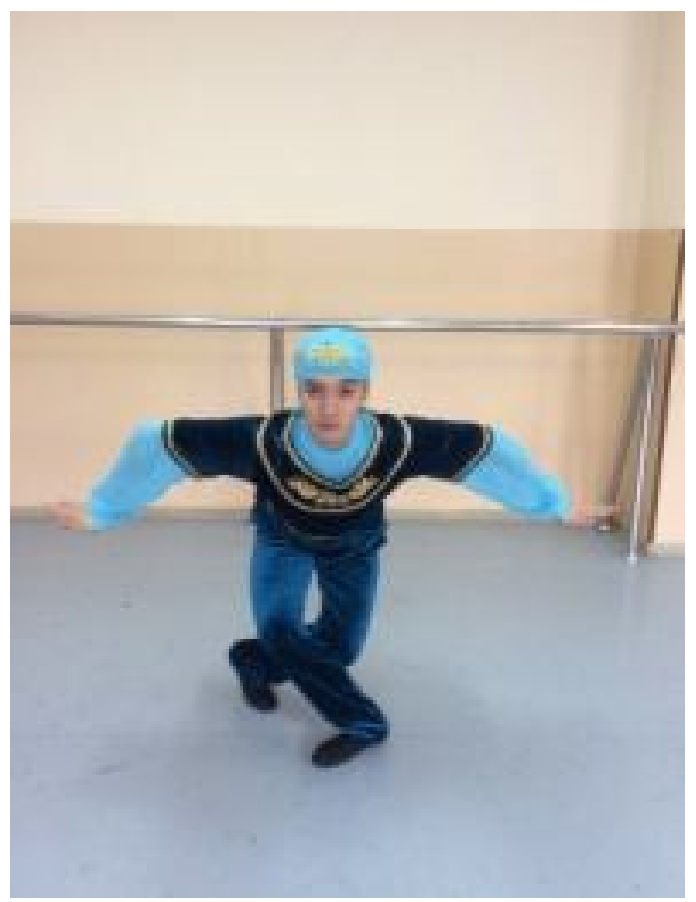

Figure 13-'Komdanu’ position

We do not rule out the possibility of the above assumption, but the subject of the petroglyph can be interpreted as totem dances. We see an image of baksy at the top left corner. His arms are stretched out to the sides and the elbows are slightly bent, as if flapping the wings before flight (fig.13). Presently, Kazakh dance has similar position called 'komdanu' (flapping the wings before flight). At the center of the image the position of the person with arms held upward, elbows drawn aside, again shows the position peculiar to Kazakh dance called 'burkit kanat' (golden eagle's wings).

Providing these comparisons, we do not exclude the probability that some zoomorphic movements of the Kazakh dance such as 'burkit kanat' (golden eagle's wings) and 'komdanu' (flapping the wings before flight) originate from baksy's dance movements.

This position, in our view, implies not only imitation of wide-open wings of a bird, but certainly, bears a deeper meaning. Golden eagle was believed to be a special bird by the Turkic peoples.

We know from history that as a bird totem an eagle was the symbol of protection. "The Bashkirs endued the feathers, fur and talons of some birds with a sacred power that can prevent 
the disease", - L.I.Nagaeva says (Nagaeva 1976). Moreover, according to some sources, from the pregnancy of a woman until 40 days after birth, people kept a golden eagle in a yurt as a counteraction from harm of a black bird, which could carry away the child's soul. To a woman giving birth in pain because of the intrusion of 'albasty' demon, they brought a golden eagle, whose gaze feared the demon. There was a custom of hanging golden eagle's claw on a cradle of the newborn. It was carried out to protect the newborn child from an evil eye and ensure his health.

The cult of golden eagle reflects the representations about the connection of this bird with the processes of revival of nature, its influence on the fertility. The image of the golden eagle is also mentioned in the beliefs of other Turkic peoples. For example, Karakalpaks hung dried corpse of a golden eagle in a yurt, so that a barren woman could give birth. To ensure a good harvest, they also hung its corpse on a pole in the middle of a field. Southwestern Turkmens called the patron of the rain and water 'Burkut-baba'. The researchers see in this patron an ancient prototype of a golden eagle. The hints of ancient representations can be traced in A. Kunanbaev's poetry, where the beloved (groom) was compared with the golden eagle, and the bride - with fox. According to the people who witnesses the baksy's rite in the recent past, "Baksy acted like an eagle. He jumped inside the yurt and kept saying "kych-kych", then instantly appeared to be on chanarak (the round dome of the yurt)" (Toleubaev 1991, p. 51). These examples show that the cult of an eagle was always revered.

In the graphic art of the Saka, an image of a golden eagle holds a significant place, and in semantic terms, it is raised to the level of a bird of the universe. We can see an image of the golden eagle, its open wings in a headdress of the Saka prince, which means that it was a sign of the Supreme power, connection with the sky and sun. Four wings adorning the Golden man's headdress, point to his divinity, to his title of a king, lord of the four corners of the world.

These facts suggest that as the totem the golden eagle was regarded as one of the strongest magical creatures, a patron. As a symbol of freedom, it is depicted on the flag of our Republic.

Summing up, zoomorphic motifs of the artifacts from Kuljabasy mountains show a ceremonial rite dedicated to a totem.

\section{Discussion of the results}

In this article the authors tried to reveal the origins of the Kazakh dance in dance movements of baksy. This aspect could not be investigated outside the historical context. The object of study was the rock paintings that convey the dialectics of the nomadic people in a remarkable manner.

The reviewed petroglyphs, rock paintings of Tamgaly gorge, Kuljabasy, Bayan-Zhurek mountains represent important institutes of accumulation and transmission of intergenerational experience, that convey the worldview of the time, a meaning, attached by the nomad to surrounding world.

Studies of ritual dance of baksy in Tamgaly petroglyph showed the origins of circle dance, born in the cult of Sun. A cult of Sun is reflected in the images of baksy going around a man for a healing purpose. It reflects the understanding of a circular movement in space, a temporal aspect. An unwinding spiral is expressed in rotational movements of the hands called 'ainalma'. 
During the study, based on the comparison of images of modern time and the artifacts, we revealed exactly the same poses of baksy and choreographic lexis of Kazakh dance. To be precise, we have revealed specific positions of hands called 'bes sausak', 'ulken syilyk', 'jogary-tomen', 'sharshy', 'burkit kanat', 'komdanu' peculiar to Kazakh dance in the dance movements of baksy. They are one of the most studied elements of Kazakh dance in our time.

When carrying out paleochoreographic analysis of rock paintings of Kazakhstan, we paid special attention to statics and kinematics of images, as well as the disclosure of these images' semantics, which made it possible to divide the dances of baksy into imitative and ecstatic type. According to the scientist D.M.Sundui, the use of this method "provides the grounds for recreation of the lost dance culture, lets develop and improve national dance folklore. In addition, the analysis will contribute to further advancement in the interdisciplinary study of a rich historical and cultural heritage of peoples, and will open new horizons for scientists doing comparative study of cultures of different peoples of the world" (Sundui 2015).

The use of structural-semantic method made it possible to reveal the semantic content of these positions. In the history of Kazakhstan science, one of the first scientists B. Ibraev, who studied the semiotic status of things, wrote: “...This is the whole subject world of the nomad, where everything, in addition to its function, carries a semantic layer that is equally important for human's life" (Ibraev198o, p. 42). The language of the Kazakh dance art as a form of generalized reflection of the past, represents "a semiotic system", so we tried to reveal the semantics of the Kazakh dance movements, reflecting national culture.

In the context of the religious belief of Tengrism, baksy performed the position 'ulken syilyk' (big gift) in his dance as a sign of worshipping the Supreme deity "Tengri”, as an appeal for the grace of God, as a gift of sacrifice.

The position 'bes sausak' (five fingers) in baksy's dance reflects the will of the Creator of all living beings and the Sky God, sending him through five main elements of nature: Sun, Earth, Water, Fire, Air.

The position 'jogary-tomen' (up and down) characterizes a baksy's dance, where his movements corresponded to nature and content of the rite, which proceeded from the very semantic essence of the ritual. This position means a flight to the Upper world, descent into the Lower world, where baksy acts as a mediator.

The position 'burkit kanat' (golden eagle's wings), 'komdanu' (flapping wings before the flight) represents the cult of worshipping totems.

The study of the topic of rock art as a graphic and semiotic system lets take a closer and deeper look at the specifics of dance language in terms of its semantic content, which made it possible to identify the nature of the dance and divide the shamanic dance into two types:

-imitative dance, demonstrated by petroglyphs (fig.11,12,13) (positions called 'burkit kanat' (golden eagle's wings), 'komdanu' (flapping wings before the flight) describe zoomorphic motifs.

-ecstatic dance - a magic dance, demonstrated in Kuljabasy artifacts (fig.7,8,9,10), the meaning of which is conveyed by the dance of a mediator shaman, flying to the Upper and Lower world). It is characterized by cosmological and geometric motifs.

According to O. Vsevolodskaya-Golushkevich, masterful transformation of baksy was carried out "for the sake of sacred aim. He tried to accomplish them as best as possible, make them more expressive, metaphorical and convincing" (Vsevolodskaya-Golushkevich 1996, p.58). It 
makes baksy the first dancer, and his dance - one of the aspects of formation of early folk dance culture of Kazakhs, one of the representatives of the phenomenon of 'baksylyk oner' (the art of baksy) (Kundakbaiuly, Ergalieva, Kuzembaeva, Zhumakova and Zhumaseitova 2012)., p. 338). Besides, according to the definition of 'baksy' by the scientist Ch.Ch. Walikhanov, given above in the article, through typological analysis of the concepts of 'baksy', 'baksylyk oner' we reveal that the word covers the meaning of an art and is important for the national dance.

\section{Conclusions}

Based on the studied scientific works and empirical and analytical researches, we have revealed the influence of dance movements of shaman and baksy on the emergence of the choreographic lexis of Kazakh dance, testified by the comparison of the rock art and images of the dance positions of present time. According to the age-date of the presented rock art, we can claim that Kazakh dance originated in ancient times. Chronological component made it possible to identify the influence of religious movements, and at the same time to reveal the semantic content of dance lexis. The study in this direction showed the basics of the development of dance lexis of national dance, where the main element is harmonious relationship of a man with the world around, his level of worldview, intellect, put into the meaning of his movements.

According to F.V. Lopukhov: "There is no thought without the look, expressing this thought and a gesture, defining it. Human movements are not meaningless, therefore, people dance" (Lopukhov 2003, p. 26.). As we see, in the presented petroglyphs, dance movements of baksy initially covered multi-layered semantic content of culture, multi-layered symbolism, which provides the opportunity to get acquainted with the essence of specific Kazakh model of understanding the world, to study the socio-cultural reality, as well as to witness the full picture of the historical emergence of national dance.

Studying the dance movements of baksy, we can conclude that the experienced and acquired phenomena, developed concepts, ideas were recorded in nomads' mind and were transformed into a drawing, depicting the language of dance. Dancing images of baksy, carved in stone, reflect symbolic concepts that they attached to the surrounding world, thus transferring some security stock of informational fund.

Summing up, this study showed that traditional dances represent an inexhaustible treasure both for choreographic and scientific researches. As a whole, all the foregoing points constitute a scientific theoretical basis, which reveals the landmarks for future ballet masters in creation of a practical component. With that, I would like to point out that this chain will lead to the possibility of achieving the basic latent idea of the study, consisting in the preservation and knowledge of the traditional image of national dance.

\section{Reference}

Akishev, K.A. (1978). Issyk kurgan. The art of Saka in Kazakhstan. Moscow: "Iskusstvo", pp. 132.

Amgalanov, M.V. (2001). Totem dances and ceremonies, shamanic rituals, domestic and religious rites as one of the sources of origin of the Mongolian and Buryat theater art. Baikal meetings-3: the culture of the peoples of Siberia. Ulan-Ude.

Avdeeva, L. (2000). From the history of Uzbek national choreography. First Book. Uzbek traditional dance art from ancient times to 2000. Moscow: Academia Publishing House, pp. 283.

Baipakov, K.M. and Maryashev, A.N. (2004). Petroglyphs in Kuljabasy mountains. Almaty: "Print S", pp. 22

Basilov, V.N. (1984). Chosen by the spirits. Moscow: Politizdat, pp. 208.

Bejart, M. (1989). Moment in the life of another. Moscow: STD, USSR 
Bernshtam, A.N. (n. d.). Saimaluu Tash rock art: Sov.etnographiya, 952(2)

Dal, V. (1956). The Explanatory Dictionary of the Living Great Russian Language. Moscow, pp. 853.

Dosbatyrov, D.K. (2013). Syncretism of traditional Kazakh culture in the light of innovations in the direction of circus and choreographic art of Kazakhstan and its integration into the world civilization. Dissertation of the PhD. Almaty, pp. 201.

Dyakonova, L.T. (2011). Dance as a phenomenon of culture. Society. Environment. Development. Terra Humana, 3, $155-158$.

Eliade, M. (2015). Shamanism, archaic techniques of ecstasy. Moscow: "Akademichesky proekt”, pp. 399.

Esaulov, I.G. (1995). The art of choreography is a science. Paleochoreography: abstracts of international scientific conference. Novosibirsk: NSTU

Gai S. (1986). Yinshan yanhua. Petroglyphs of Yinshan mountains. Beijing

Gai S. (1993). Cong Neimeng Yinshan yanhua kan gudai beifang youmu minzu de lishi gongxian [historical role of the ancient nomads of the North in the rock art of Yinshan mountains in Inner Mongolia. Sichou zhi lu yanhua yishu [Rock art on the Silk road]. Ürümqi, 1993, 1-8.

Gai S. (1999). Caoyuan xunmeng [Search for your dream in the steppe]. Jinan

Georgi, I.I. (1777). Description of all the nations living in Russian government. St. Petesburg, pp. 123.

Hermann L. (2011). Rock Art of Tamgaly in Kazakhstan. Adoranten, p. 35.

Hoopwood C.E. and Beardmore R. (2003). Survey and excavation at Eshki - Olmes and Kuldzhabacy, Kazakhstan: A bid for UNESCO world heritage status. Circle of Inner Asian Art. (CIAA) SOAS. Newsletter issue 18 - December. p. 3 - 11

Ibraev, B. (1980). Cosmogonic views of our ancestors. Decorative art of the USSR, 8, $40-45$.

Ibragimova, G.K. (2004). Traditions of ornamental compositions in the Kazakh jewelry art. Collection of articles of the international scientific and practical conference held by KazNAA after T.Zhurgenov, Vol. 1. "Cultural heritage of the peoples of Kazakhstan and the national education system", April 29 - 30, 2004. Almaty: "Voluntary society of disabled people of war in Afghanistan-Brotherhood" publishing house, pp. 338.

Izim, T. and Kulbekova, A. (2012). Theory and method of teaching Kazakh dance. Textbook. Astana: "Tengri Ltd", pp. 200.

Kadyrbaev, M.K., and Maryashev, A.N. (2007). Petroglyphs of Karatau ridge: 2nd edition. Almaty: Print S, pp. 147.

Kishkashbaev, T.A., Shankibaeva, A., Mambetova, L., Jumaseitova,G. and Musina, F. (2005). History of choreography in Kazakhstan. Almaty: IzdatMarket, pp. 272.

Knox W. (1877). Journey in Russia. Washington, pp.144.

Koroleva, E. A. (1977). Early forms of dance. Kishinev: Shtiintsa, pp. 215.

Kundakbaiuly, B., Ergalieva, R.A., Kuzembaeva, S.A., Zhumakova, U.R. and Zhumaseitova, G.T. (2011). History of Kazakh art. Ancient period. Volume1. Almaty: Arda + 7, pp. 416

Kundakbaiuly, B., Ergalieva, R.A., Kuzembaeva, S.A., Zhumakova, U.R. and Zhumaseitova, G.T. (2012). History of Kazakh art. Medieval period. Volume 2. Almaty: Arda+7, pp. 448

Lopukhov, F.V. (2003). Into the depth of choreography. Moscow: "Folium" publishing house, pp. 190.

Mahlina, S.T. (2008). Semiotics of sacred religious ideas. St. Petesburg: "Alateya", pp. 171.

Maksimova, A.G. (1958). Rock art of Tamgaly Gorge. Vestnik AN KazSSR, 9 (162), 108-110

Malov, S.E. (1912). Shamanism of the Sarts of Eastern Turkestan. Remains of shamanism of Yellow Uighurs. St. Petersburg: Zhivaya starina

Margulan, A.Kh. (2003). Compositions. Vol.3-4: Petroglyphs of Sary-Arka. Engravings with the images of wolf totem; Ulytau stone sculptures. Almaty: "Atamura”, pp. 246.

Marikovsky, P.I. (1950). On rock art in Chulak mountains. Almaty: VAN KazSSR, pp. 103.

Medoev, A. (1979). Rock engravings. Sary-Arka, Mangyshlak. Alma-Ata: "Jalyn", pp. 174.

Moldakhmetova, A.T. (2016). Thesis for a degree of Master of Arts. Reflection of traditional culture in the semantics of the Kazakh dance lexis. Almaty, pp. 87.

Nagaeva, L.I. (1976). Eastern Bashkir Dance. Moscow: "Nauka” pub.house, pp. 67-72.

Nikonov, A.Y. (2014). Tengriism. At the origins of the spirituality of mankind. Almaty: Tsennye bumagi, pp. 88.

Oestigaard T. (2011). Cosmogony. New York: Press Inc., pp. 76-88. 
Okladnikov, A.P. (1980). Petroglyphs of Central Asia. Leningrad: “Nauka”, pp. 269.

Price N. (2011). Shamanism. New York: Press Inc., pp. 983-1003.

Rogozhinsky, A.E. (2011). Petroglyphs of Tamgaly archaeological landscape. Almaty: Signet Print, pp. 342.

Romm, V.V. (n. d.). Dance as a factor of evolution of human culture. Dissertation of the doctor of culturology. Barnaul, pp. 403.

Rozwadowski, A. (2001a). The Petroglyphs of Central Asia from the viewpoint of the Indo-Iranian Hypothesis. Indo-European Studies Bulletin, 9(2), 9-19.

Rozwadowski, A. (2001b). Sun Gods or Shaman? Interpreting the Solar-Headed Petroglyphs of Central Asia. In The Archaeology of Shamanism. London: Routledge, pp. 65-86.

Sagalaev, A.M. and Oktyabrskaya, I.V. (1990). Traditional worldview of South Siberian Turks. Sign and ritual. Novosibirsk: Nauka, Siberian branch, pp. 209.

Saitova, G.Y. (2011). Uighur dance: Origins. Traditions. Stage impersonation. Almaty: "Mir", pp. 180.

Samashev, Z. (1993). Petroglyphs of East Kazakhstan as a historical source. Almaty, pp. 238.

Samashev, Z. (1998). Les petroglyphes medievaux du Kazakhstan. Fnalyges ef inforpretafions Recherches archeologiaques au Kazakhstan. Memoires du la miesion Archeologiques francain en Asie Centrale. Paris, pp. 103-112.

Samashev, Z. (1998). Shamans in the petroglyphs of Kazakhstan. (For the study of the ancient people's worldview). Issues of Kazakhstan archeology. Almaty - Moscow

Samashev, Z. (2002). Shamanic motifs in the petroglyphs of Eastern Kazakhstan. Spirits and Stones. Shamanism and Rock Art in Central Asia and Siberia. Poznan, pp. 33-48.

Samashev, Z. (2006). Petroglyphs Of Kazakhstan. Almaty: Oner, pp. 99.

Shankibaeva, A.B. (2011). Kazakh choreography: development of forms and artistic means. Monograph. Almaty: "IP Volkova N.A.", pp. 152.

Shinkevich, P.O. (1896). Materials for the study of shamanism of Golds. Notes of Russian Geographical Society for the Study of the Amur region, 1896, V.2, Ed. I. The same author. Customs, beliefs and traditions of Golds. Ethnographic review.

Sternberg, L.Y. (1933). Giliaki, Orochi, Gol'dy, Negidal'tsy, Ainy: Articles, materials. Khabarovsk

Sundui, D.M. (2015). Paleochoreography in Tuva rock art. Herald of Tomsk State University. History, 3 (35), 123-127.

Tihonov, V.M. and Kan M. (2011). History of Korea: in 2 volumes. Vol.1. Moscow: Vostochnaya kniga, pp. 544 .

Tokarev, S. A. (1965). Religion in the history of the peoples of the world. 2nd ed., edited and amended. Moscow: Politizdat, pp. 623

Toleubaev, A.T. (1991). Relics of pre-Islamic beliefs in Kazakh family rites. - Alma-Ata: Qylym, pp. .213.

Tskhai, A.S. (2016). Korean stage dance in the context of the formation and development of the choreography of Kazakhstan and its integration into the world space. Dissertation of the PhD. Almaty, pp. 151.

Tursunov, E.D. (1999). Origin of baksy, akyn, seri, zhyrau. Astana: Foliant publishing house, pp. 252.

Varlamov, O.B. (1995). Shamanism of Western Buryats. Legends and rituals. Irkutsk: "Uliss"

Vinnikov, I.N. (1934). A legend on Muhammad's mission in terms of ethnography. Leningrad, pp. 125-146

Vsevolodskaya-Golushkevich, O.V. (1994). Kazakh dance school. Almaty: Oner, pp. 184.

Vsevolodskaya-Golushkevich, O.V. (1996). Baksy oiyny. Almaty: "Rauan", pp. 144.

Walikhanov, Ch.Ch. (1961). Collected edition in 5 volumes, vol.1. Alma-Ata: Publishing house of AS of KazSSR, pp. 431.

Walikhanov, Ch.Ch. (1985). Traces of shamanism in Kyrgyz tradition. Five-volume collection: Vol.4. Almaty

Wang, P. (2005). The power of Numbers in Shamanism: A Patterned Explanation of Shaman Names in Inner Asia. Journal of Central Asian Studies, 7(1), 1-34.

Whitley D.S. (2011). Rock art, Religion, and Ritual. New York: Press Inc., pp. 307-328.

World Heritage List. Petroglyphs within the Archaeological Landscape of Tamgaly. http://whc.unesco.org/en/list/1145 (accessed 01.12.2015).

Zaurbekova, L. and Dzhumanova, G. (2000). Kazakh worldview. Traditional culture of nomads. Almaty: KazNAA after T.Zhurgenov, pp. 43-59.

Zenovich, E. (2000). Dictionary of foreign words and phrases. Moscow: AST, Olimp-Astrel, pp. 784 . 